\title{
Applying the grey clustering method to assess water quality in a watershed in Cusco, Peru
}

\author{
Alexi Delgado, $\mathrm{PhD}^{1}$, Acuña M., BSc${ }^{2}$, Justano N., BSc${ }^{2}$, Llanos E., BSc ${ }^{2}$, Puma I., BSc ${ }^{2}$ and Chiara Carbajal, BSc ${ }^{3}$ \\ ${ }^{1}$ Pontificia Universidad Católica del Perú, Lima, Peru, kdelgadov@pucp.edu.pe \\ ${ }^{2}$ Universidad Nacional de Ingeniería, Lima, Peru, kdelgadod@uni.edu.pe \\ ${ }^{3}$ Universidad de Ciencias y Humanidades, Lima, Peru, ccarbajal@uch.edu.pe
}

\begin{abstract}
Water quality assessment is a current issue of increasing concern in many countries around the world for reasons such as population health, national economic development and the environmental quality of ecosystems. At this juncture, the Grey Clustering method is used to assess water quality at discharge points, from the beginning to the end of the environmental monitoring process in the area of influence of the Anabi mining unit in the Chonta and Milos micro-watershed. The parameters evaluated were pH, dissolved oxygen, total suspended solids (TSS), iron and manganese. The results obtained through the Grey Clustering methodology showed a monitoring point with contamination from a treated water discharge. On the other hand, in order to obtain greater efficiency in the evaluation of water quality, national standard DS 004-2017-Minam (Water Quality Standards) and international standards were used through the PRATI index. Through the results obtained it was observed that (by means of the Prati index) there is a better classification of the water quality in each point, therefore this research becomes an important tool for future studies to consider the Prati index for greater reliability of results.
\end{abstract}

Keywords-- Grey Clustering, Water parameters, Water quality.

\section{INTRODUCTION}

Quiñota district is located to the northwest of Chumbivilcas Province, and west of Cusco region, in the mountains of Peru [1]; it is in this district where ANABI SAC is placed, a mining company that exploits gold and silver since 2010 (with a capacity of one thousand tons per day), the year in which it obtained its certification. However, every year there have been confrontations with the people of Cusco who denounced the company for generating pollution, which evidently causes a state of tension in the social area of the community mentioned [2]. In addition to the disputes generated by the company's activities, environmental impacts were generated towards the water component, as evidenced by the environmental complaints that can be found in the SINADA since 2012 [3], which would turn the resource into an area of potential interest. In addition, it is important to ensure that the quality of water is assessed considering the vital importance of this resource for life, not to mention its social and ecosystem value [4].

The present study used the Grey Clustering method, which is used to analyze studies with limited samples [5]. In the present case it was used to analyze the results of the water monitoring of 6 stations within the area of influence of the Anabi mining unit. In addition, 2 evaluation standards, the Prati index [6] and the water ECA [7] were used for greater reliability of the result.

Digital Object Identifier (DOI):

http://dx.doi.org/10.18687/LACCEI2020.1.1.524

ISBN: 978-958-52071-4-1 ISSN: 2414-6390
Thus, in the present research, the Grey Clustering methodology is presented in section II, followed by a description of the case study and the application of the method in the case study by comparing two standards, ECA water and the Prati index, can be found in section III. The results and discussions are then presented in section IV. Finally, section V provides the conclusions of this study.

\section{METHODOLOGY}

The Grey clustering method is grounded in the grey systems theory developed in 1985 by Deng [8], which examines the problems of small samples with limited information. Therefore, considering that in the real world there are many problems of this nature, its application extends to many fields such as water management [9].

Step 1:

The assessment standards for each water quality parameter, agreed on the scale of the Environmental Quality Standard (ECA) [7] and the Prati index [6], are adjusted. Then the monitoring data, obtained in the field, are also dimensioned for each parameter.

Step 2:

The five classes of the PRATI scale are shown in Fig. 1.

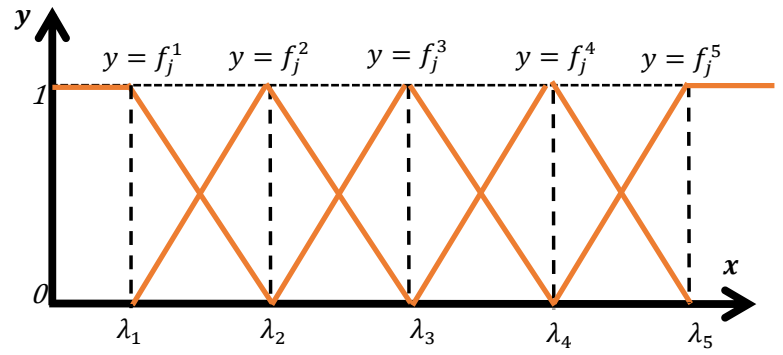

Fig. 1 The Grey graphics evaluated for each parameter.

Where:

$y=f_{j}^{1}$ : Uncontaminated

$y=f_{j}^{2}:$ Acceptable

$y=f_{j}^{3}$ : Moderate pollution

$y=f_{j}^{4}$ : Polluted

$y=f_{j}^{5}$ : High pollution

The Grey classes $k=1,2,3,4,5$ and $j=1,2,3,4,5 \ldots n$ are then established for the evaluation of the monitoring and are calculated using (1-3) shown below.

18th LACCEI International Multi-Conference for Engineering, Education, and Technology: "Engineering, Integration, and Alliances for a Sustainable Development" "Hemispheric Cooperation for Competitiveness and Prosperity on a Knowledge-Based Economy", July 27-31, 2020, Virtual 


$$
\begin{aligned}
& f_{j}^{1}\left(x_{i j}\right)=\left\{\begin{array}{cc}
1, & x \in\left[0, \lambda_{j}^{1}\right] \\
\frac{\lambda_{j}^{2}-\mathrm{x}}{\lambda_{j}^{2}-\lambda_{j}^{1}}, & x \in\left\langle\lambda_{j}^{1}, \lambda_{j}^{2}\right\rangle \\
0, & x \in\left[\lambda_{j}^{2},+\infty\right\rangle
\end{array}\right. \\
& f_{j}^{k}\left(x_{i j}\right)=\left\{\begin{array}{cc}
\frac{x-\lambda_{j}^{k-1}}{\lambda_{j}^{k}-\lambda_{j}^{k-1}}, & x \in\left\langle\lambda_{j}^{k-1}, \lambda_{j}^{k}\right] \\
\frac{\lambda_{j}^{k+1}-\mathrm{x}}{\lambda_{j}^{k+1}-\lambda_{j}^{k}}, & x \in\left\langle\lambda_{j}^{k}, \lambda_{j}^{k+1}\right\rangle \\
0, & x \in\left[0, \lambda_{j}^{k-1}\right] \cup\left[\lambda_{j}^{k-1},+\infty\right\rangle
\end{array}\right. \\
& f_{j}^{5}\left(x_{i j}\right)=\left\{\begin{array}{cc}
\frac{x-\lambda_{j}^{4}}{\lambda_{j}^{5}-\lambda_{j}^{4}}, & x \in\left\langle\lambda_{j}^{4}, \lambda_{j}^{5}\right\rangle \\
1, & x \in\left[\lambda_{j}^{5},+\infty\right\rangle \\
0, & x \in\left[0, \lambda_{j}^{4}\right]
\end{array}\right.
\end{aligned}
$$

Step 3:

Equation (4) is used to calculate the clustering weight according to the Prati scale.

$$
n_{j}^{k}=\frac{\frac{1}{\lambda_{j}^{k}}}{\sum_{j=1}^{m} \frac{1}{\lambda_{j}^{k}}}
$$

Step 4:

The clustering coefficient for each monitoring point $i=$ $1,2, \ldots m$ with respect to Grey class $k=1,2,3 \ldots . s$ is calculated by (5):

$$
\sigma_{i}^{k}=\sum_{j=1}^{n} f_{j}^{k}\left(x_{i j}\right) \cdot n_{j}
$$

Where $f_{j}^{k}\left(x_{i j}\right)$ is the CTWF evaluation and $n_{j}$ is the weight of parameters $j$.

Step 5:

If $\quad \max _{1 \leq k \leq s}\left\{\sigma_{i}^{k}\right\}=\sigma_{i}^{k *}$, it is decided that the object belongs to the Grey class $k *$.

\section{CASE STUDY}

The Anabi mining unit is located in the eastern part of the Cordillera Occidental Andina (as it may be seen in Fig. 2); its direct area of influence is the district of Quiñota, province of Chumbivilcas, in the department of Cusco. This study will focus on the Chonta micro watershed and the Milos Creek.



Fig. 2 Anabi mining unit location.

The issues in this area are mainly the high socioenvironmental conflict between civil society and the mining company, as there is non-compliance with environmental commitments [10]. The population denounced the environmental impact on the components water, soil and air.

Among the parameters to be evaluated are the two heavy metals considered the most toxic, such as Iron and Manganese, which have the features of persistence in ecosystems for a long time and the ability to accumulate in successive levels of the trophic chain [11].

Iron $(\mathrm{Fe})$ in nature is mainly found as sulphides (FeS2), and the main sources of contamination of this metal are derived from mining and metallurgical operations. The oxidative dissolution of pyrite results in acid mine drains [12].

Manganese is one of the most abundant elements in the earth's crust and is found in minerals in rocks and soils, these being significant sources of the element as it dissolves in surface waters. In aquatic ecosystems the solubility of manganese decreases the $\mathrm{pH}$ value, as well as at low levels of redox potential [13].

The sampling points evaluated are shown in Table I.

TABLE I

SAMPLING POINT LOCATIONS

\begin{tabular}{|c|c|c|c|}
\hline \multirow{2}{*}{ Code } & \multicolumn{2}{|c|}{$\begin{array}{c}\text { Coordinates UTM Datum WGS 84 } \\
\text { Zone 18 L }\end{array}$} & $\begin{array}{c}\text { Altitude } \\
\text { (MASL) }\end{array}$ \\
\cline { 2 - 3 } & East (m) & North (m) & \\
\hline QCho-04 & 792841 & 8399217 & 4388 \\
\hline QCho-06 & 793469 & 8399581 & 4373 \\
\hline QCho-07 & 793507 & 8399648 & 4364 \\
\hline QCho-08 & 793562 & 8399770 & 4365 \\
\hline QCho-10 & 793986 & 8400196 & 4335 \\
\hline QMil-02 & 793499 & 8399920 & 4371 \\
\hline
\end{tabular}


Table II also shows the description of each sampling point, which is important to know the source of the water analyzed at each point.

\begin{tabular}{|l|l|}
\hline QCho-07 & $\begin{array}{l}\text { Discharge A, treated industrial water from the } \\
\text { dump. }\end{array}$ \\
\hline QCho-08 & Downstream of dumping A. \\
\hline QCho-10 & Downstream of the pit. \\
\hline QMil-02 & Prior to the confluence with Chonta Creek. \\
\hline
\end{tabular}

In order to have a better appreciation of the abovementioned context, a map with the location of the monitoring points indicated can be appreciated in Fig. 3.

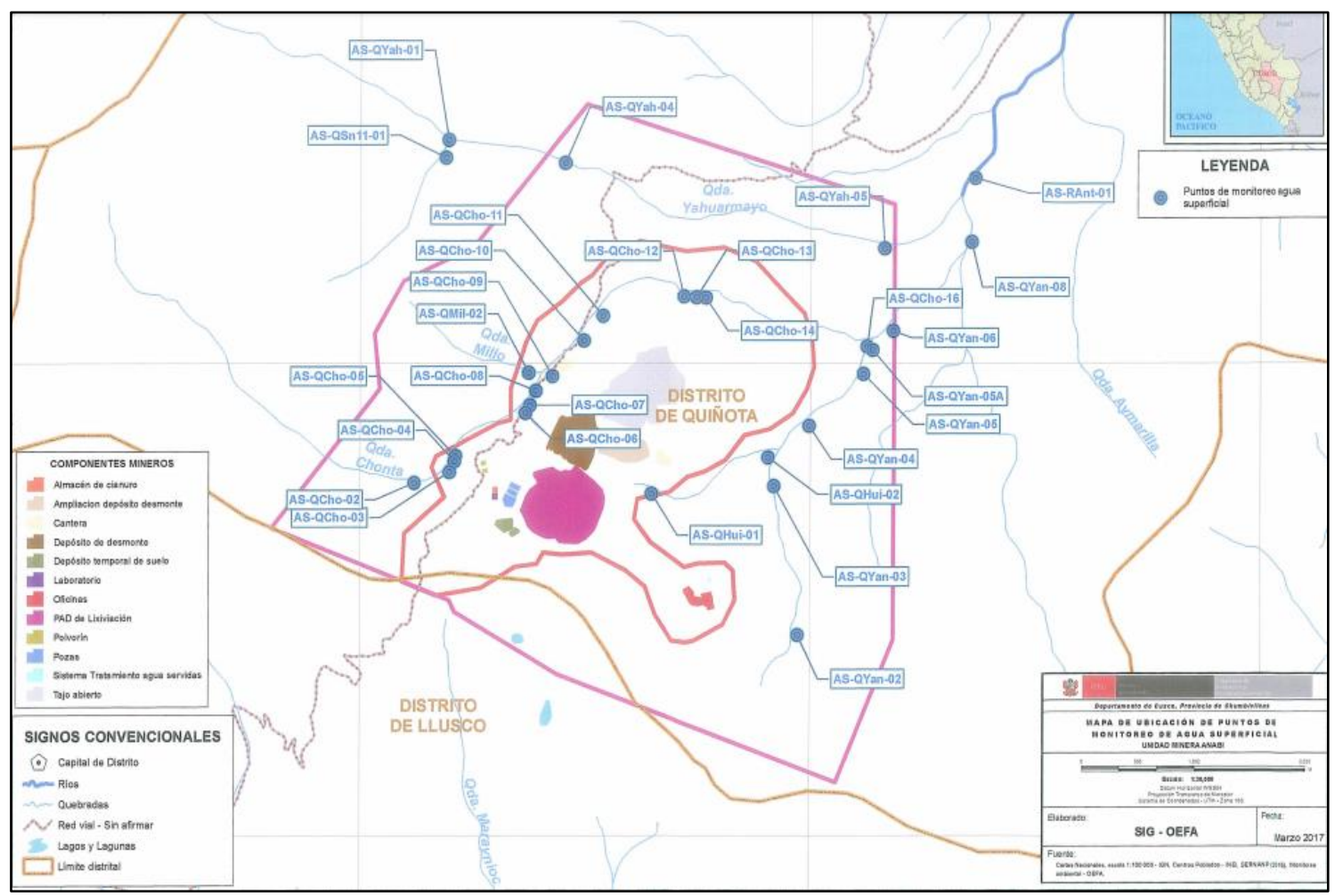

Fig. 3 Monitoring points location map.

A. Calculations using Grey Clustering.

The nomenclatures to use for the development of the calculations are shown in Tables III and IV.

TABLE III

STANDARD DATA NOMENCLATURE

\begin{tabular}{|c|c|}
\hline AS-Qcho-04 & P1 \\
\hline AS-Qcho-06 & P2 \\
\hline AS-Qcho-07 & P3 \\
\hline AS-Qcho-08 & P4 \\
\hline AS-Qcho-10 & P5 \\
\hline AS-Mil-02 & P6 \\
\hline
\end{tabular}

TABLE IV

SAMPLING POINTS NOMENCLATURE

\begin{tabular}{|c|c|}
\hline $\mathrm{pH}$ & $\mathrm{C} 1$ \\
\hline $\mathrm{OD}$ & $\mathrm{C} 2$ \\
\hline TSS & $\mathrm{C} 3$ \\
\hline Iron & $\mathrm{C} 4$ \\
\hline Manganese & $\mathrm{C} 5$ \\
\hline
\end{tabular}

Field sampling data is given in Table V. 
TABLE V

SAMPLING DATA

\begin{tabular}{|c|c|c|c|c|c|}
\hline & C1 & C2 & C3 & C4 & C5 \\
\hline P1 & 4.792 & 6.630 & 3.000 & 0.810 & 1.033 \\
\hline P2 & 7.350 & 5.460 & 3.000 & 0.208 & 0.099 \\
\hline P3 & 6.580 & 5.420 & 8.000 & 0.540 & 0.140 \\
\hline P4 & 7.135 & 5.640 & 4.400 & 0.241 & 0.119 \\
\hline P5 & 6.829 & 5.940 & 4.800 & 0.292 & 0.143 \\
\hline P6 & 6.742 & 5.550 & 3.000 & 0.183 & 0.108 \\
\hline
\end{tabular}

In the following, calculations will be presented using the Environmental Quality Standards (ECA by its Spanish acronym) and then the Prati index.

1) With national standards (Environmental Quality Standards - category 1)

Table VI presents the standard data of the parameters obtained from DS 004-2017-Minam.

TABLE VI

STANDARD DATA ACCORDING TO DS 004-2017-MINAM

\begin{tabular}{|c|c|c|c|}
\hline & $\mathbf{A 1}$ & $\mathbf{A 2}$ & $\mathbf{A 3}$ \\
\hline $\mathrm{C} 1$ & 7.5 & 7.25 & 7 \\
\hline $\mathrm{C} 2$ & 3 & 2.5 & 2 \\
\hline $\mathrm{C} 3$ & 0.8 & 1 & 1.2 \\
\hline $\mathrm{C} 4$ & 0.3 & 1 & 5 \\
\hline $\mathrm{C} 5$ & 0.4 & 0.45 & 0.5 \\
\hline
\end{tabular}

a) Data dimensioning

The dimensioned data according to RCT data are displayed in Table VII.

TABLE VII

DIMENSIONING OF STANDARD DATA ACCORDING TO ENVIRONMENTAL QUALITY STANDARDS

\begin{tabular}{|c|c|c|c|c|c|}
\hline & C1 & C2 & C3 & C4 & C5 \\
\hline P1 & 0.661 & 2.652 & 3.000 & 0.386 & 2.296 \\
\hline P2 & 1.014 & 2.184 & 3.000 & 0.099 & 0.219 \\
\hline P3 & 0.908 & 2.168 & 8.000 & 0.257 & 0.311 \\
\hline P4 & 0.984 & 2.256 & 4.400 & 0.115 & 0.264 \\
\hline P5 & 0.942 & 2.376 & 4.800 & 0.139 & 0.318 \\
\hline P6 & 0.930 & 2.220 & 3.000 & 0.087 & 0.240 \\
\hline
\end{tabular}

The monitoring data obtained from the report of the Environmental Assessment and Control Agency (OEFA by its Spanish acronym) for each parameter are shown in Table VIII.
TABLE VIII

DIMENSIONING OF THE SAMPLING DATA

\begin{tabular}{|c|c|c|c|}
\hline & $\mathbf{A 1}$ & $\mathbf{A 2}$ & $\mathbf{A 3}$ \\
\hline $\mathrm{C} 1$ & 1.034 & 1.000 & 0.966 \\
\hline $\mathrm{C} 2$ & 1.200 & 1.000 & 0.800 \\
\hline $\mathrm{C} 3$ & 0.800 & 1.000 & 1.200 \\
\hline $\mathrm{C} 4$ & 0.143 & 0.476 & 2.381 \\
\hline $\mathrm{C} 5$ & 0.889 & 1.000 & 1.111 \\
\hline
\end{tabular}

\section{b) Parameter weights}

In Table IX, the weights of each parameter are calculated through (4).

TABLE IX

PARAMETER WEIGHTS

\begin{tabular}{|c|c|c|c|}
\hline & A1 & A2 & A3 \\
\hline C1 & 0.087 & 0.164 & 0.233 \\
\hline C2 & 0.075 & 0.164 & 0.282 \\
\hline C3 & 0.112 & 0.164 & 0.188 \\
\hline C4 & 0.626 & 0.344 & 0.095 \\
\hline C5 & 0.101 & 0.164 & 0.203 \\
\hline
\end{tabular}

c) Whitenization Functions

The clustering coefficients were calculated using (5). The results are displayed in Table $\mathrm{X}$.

$$
\text { TABLE } X
$$

WHITENIZATION FUNCTIONS

\begin{tabular}{|c|c|c|c|c|c|}
\hline AS-Qcho-04 & $\mathbf{C 1}$ & $\mathbf{C 2}$ & $\mathbf{C 3}$ & $\mathbf{C 4}$ & $\mathbf{C 5}$ \\
\hline$f_{1}$ & 0.000 & 1.000 & 0.000 & 0.271 & 0.000 \\
\hline$f_{2}$ & 0.000 & 0.000 & 0.000 & 0.729 & 0.000 \\
\hline$f_{3}$ & 1.000 & 0.000 & 1.000 & 0.000 & 1.000 \\
\hline AS-Qcho-06 & $\mathbf{C 1}$ & $\mathbf{C 2}$ & $\mathbf{C 3}$ & $\mathbf{C 4}$ & $\mathbf{C 5}$ \\
\hline$f_{1}$ & 0.000 & 1.000 & 0.000 & 1.000 & 1.000 \\
\hline$f_{2}$ & 0.600 & 0.000 & 0.000 & 0.000 & 0.000 \\
\hline$f_{3}$ & 0.400 & 0.000 & 1.000 & 0.000 & 0.000 \\
\hline $\mathbf{A S - Q c h o - 0 7}$ & $\mathbf{C 1}$ & $\mathbf{C 2}$ & $\mathbf{C 3}$ & $\mathbf{C 4}$ & $\mathbf{C 5}$ \\
\hline$f_{1}$ & 0.000 & 1.000 & 0.000 & 0.657 & 1.000 \\
\hline$f_{2}$ & 0.000 & 0.000 & 0.000 & 0.343 & 0.000 \\
\hline$f_{3}$ & 1.000 & 0.000 & 1.000 & 0.000 & 0.000 \\
\hline $\mathbf{A S}-\mathbf{Q c h o - 0 8}$ & $\mathbf{C 1}$ & $\mathbf{C 2}$ & $\mathbf{C 3}$ & $\mathbf{C 4}$ & $\mathbf{C 5}$ \\
\hline$f_{1}$ & 0.000 & 1.000 & 0.000 & 1.000 & 1.000 \\
\hline$f_{2}$ & 0.000 & 0.000 & 0.000 & 0.000 & 0.000 \\
\hline$f_{3}$ & 1.000 & 0.000 & 1.000 & 0.000 & 0.000 \\
\hline $\mathbf{A S - Q c h o - 1 0}$ & $\mathbf{C 1}$ & $\mathbf{C 2}$ & $\mathbf{C 3}$ & $\mathbf{C 4}$ & $\mathbf{C 5}$ \\
\hline$f_{1}$ & 0.000 & 1.000 & 0.000 & 1.000 & 1.000 \\
\hline$f_{2}$ & 0.000 & 0.000 & 0.000 & 0.000 & 0.000 \\
\hline$f_{3}$ & 1.000 & 0.000 & 1.000 & 0.000 & 0.000 \\
\hline & & & & \\
\hline & & & \\
\hline
\end{tabular}




\begin{tabular}{|c|c|c|c|c|c|}
\hline AS-Mil-02 & C1 & C2 & C3 & C4 & C5 \\
\hline$f_{1}$ & 0.000 & 1.000 & 0.000 & 1.000 & 1.000 \\
\hline$f_{2}$ & 0.000 & 0.000 & 0.000 & 0.000 & 0.000 \\
\hline$f_{3}$ & 1.000 & 0.000 & 1.000 & 0.000 & 0.000 \\
\hline
\end{tabular}

\section{d) Grey Class}

Finally, the maximum value of each point sampled (highlighted in yellow for a better appreciation) will be the grey class, which indicates the quality of the water. Results can be seen in Table XI.

TABLE XI

VALUES OBTAINED FROM EACH MONITORING POINT

\begin{tabular}{|c|c|c|c|c|}
\hline & Standard data nomenclature & $\mathbf{A 1}$ & $\mathbf{A 2}$ & $\mathbf{A 3}$ \\
\hline P1 & AS-Qcho-04 & 0.2446 & 0.2508 & 0.6238 \\
\hline P2 & AS-Qcho-06 & 0.8016 & 0.0984 & 0.2811 \\
\hline P3 & AS-Qcho-07 & 0.5869 & 0.1180 & 0.4210 \\
\hline P4 & AS-Qcho-08 & 0.8016 & 0.0000 & 0.4210 \\
\hline P5 & AS-Qcho-10 & 0.8016 & 0.0000 & 0.4210 \\
\hline P6 & AS-Mil-02 & 0.8016 & 0.0000 & 0.4210 \\
\hline
\end{tabular}

\section{2) With Prati Index}

The same procedure described in point 1) with national standards (Environmental Quality Standards - category 1) is shown below, with the difference that values obtained by the Prati index will be used. These standard data can be seen in Table XII.

TABLE XII

STANDARD DATA ACCORDING TO PRATI

\begin{tabular}{|c|c|c|c|c|c|}
\hline & $\boldsymbol{\lambda}^{\mathbf{1}}$ & $\boldsymbol{\lambda}^{\mathbf{2}}$ & $\boldsymbol{\lambda}^{\mathbf{3}}$ & $\boldsymbol{\lambda}^{\mathbf{4}}$ & $\boldsymbol{\lambda}^{\mathbf{5}}$ \\
\hline $\mathrm{C} 1$ & 7.25 & 6.25 & 5.5 & 4.45 & 2.45 \\
\hline $\mathrm{C} 2$ & 100 & 118.5 & 137.5 & 175 & 212.5 \\
\hline $\mathrm{C} 3$ & 10 & 30 & 70 & 189 & 308 \\
\hline $\mathrm{C} 4$ & 0.05 & 0.2 & 0.6 & 1.8 & 3 \\
\hline $\mathrm{C} 5$ & 0.025 & 0.11 & 0.335 & 0.75 & 1.165 \\
\hline
\end{tabular}

a) Data dimensioning

The dimensioned data according to Prati data are presented in Table XIII.

TABLE XIII

DIMENSIONING OF STANDARD DATA ACCORDING TO PRATI

\begin{tabular}{|c|c|c|c|c|c|}
\hline & C1 & C2 & C3 & C4 & C5 \\
\hline P1 & 0.925 & 0.439 & 0.025 & 0.717 & 2.166 \\
\hline P2 & 1.419 & 0.362 & 0.025 & 0.184 & 0.206 \\
\hline P3 & 1.270 & 0.359 & 0.066 & 0.478 & 0.294 \\
\hline P4 & 1.377 & 0.374 & 0.036 & 0.213 & 0.249 \\
\hline P5 & 1.318 & 0.394 & 0.040 & 0.258 & 0.300 \\
\hline P6 & 1.302 & 0.368 & 0.025 & 0.162 & 0.226 \\
\hline
\end{tabular}

The monitoring data obtained from the OEFA report for each parameter are shown in table XIV.

TABLE XIV

DIMENSIONING OF SAMPLE DATA

\begin{tabular}{|c|c|c|c|c|c|}
\hline & $\boldsymbol{\lambda}^{\mathbf{1}}$ & $\boldsymbol{\lambda}^{\mathbf{2}}$ & $\boldsymbol{\lambda}^{\mathbf{3}}$ & $\boldsymbol{\lambda}^{\mathbf{4}}$ & $\boldsymbol{\lambda}^{\mathbf{5}}$ \\
\hline $\mathrm{C} 1$ & 1.400 & 1.207 & 1.062 & 0.859 & 0.473 \\
\hline $\mathrm{C} 2$ & 0.672 & 0.797 & 0.925 & 1.177 & 1.429 \\
\hline $\mathrm{C} 3$ & 0.082 & 0.247 & 0.577 & 1.557 & 2.537 \\
\hline $\mathrm{C} 4$ & 0.044 & 0.177 & 0.531 & 1.593 & 2.655 \\
\hline $\mathrm{C} 5$ & 0.052 & 0.231 & 0.702 & 1.572 & 2.442 \\
\hline
\end{tabular}

\section{b) Parameter weights}

In table $\mathrm{XV}$, the weights of each parameter are calculated using (4).

Table XV

PARAMETER WEIGHTS

\begin{tabular}{|c|c|c|c|c|c|}
\hline & $\lambda^{\mathbf{1}}$ & $\lambda^{2}$ & $\lambda^{3}$ & $\lambda^{4}$ & $\lambda^{5}$ \\
\hline $\mathrm{C} 1$ & 1.400 & 1.207 & 1.062 & 0.859 & 0.473 \\
\hline $\mathrm{C} 2$ & 0.672 & 0.797 & 0.925 & 1.177 & 1.429 \\
\hline $\mathrm{C} 3$ & 0.082 & 0.247 & 0.577 & 1.557 & 2.537 \\
\hline $\mathrm{C} 4$ & 0.044 & 0.177 & 0.531 & 1.593 & 2.655 \\
\hline $\mathrm{C} 5$ & 0.052 & 0.231 & 0.702 & 1.572 & 2.442 \\
\hline
\end{tabular}

c) Whitenization Functions

The clustering coefficients are calculated using (5). The results are showed in Table XVI.

TABLE XVI

WHITENIZATION FUNCTIONS VALUES

\begin{tabular}{|c|c|c|c|c|c|}
\hline AS-Qcho-04 & $\mathbf{C 1}$ & $\mathbf{C 2}$ & $\mathbf{C 3}$ & $\mathbf{C 4}$ & $\mathbf{C 5}$ \\
\hline$f_{1}$ & 0.000 & 1.000 & 1.000 & 0.000 & 0.000 \\
\hline$f_{2}$ & 0.000 & 0.000 & 0.000 & 0.000 & 0.000 \\
\hline$f_{3}$ & 0.325 & 0.000 & 0.000 & 0.825 & 0.000 \\
\hline$f_{4}$ & 0.675 & 0.000 & 0.000 & 0.175 & 0.317 \\
\hline$f_{5}$ & 0.000 & 0.000 & 0.000 & 0.000 & 0.683 \\
\hline AS-Qcho-06 & $\mathbf{C 1}$ & $\mathbf{C 2}$ & $\mathbf{C 3}$ & $\mathbf{C 4}$ & $\mathbf{C 5}$ \\
\hline$f_{1}$ & 1.000 & 1.000 & 1.000 & 0.000 & 0.140 \\
\hline$f_{2}$ & 0.000 & 0.000 & 0.000 & 0.980 & 0.860 \\
\hline$f_{3}$ & 0.000 & 0.000 & 0.000 & 0.020 & 0.000 \\
\hline$f_{4}$ & 0.000 & 0.000 & 0.000 & 0.000 & 0.000 \\
\hline$f_{5}$ & 0.000 & 0.000 & 0.000 & 0.000 & 0.000 \\
\hline AS-Qcho-07 & $\mathbf{C 1}$ & $\mathbf{C 2}$ & $\mathbf{C 3}$ & $\mathbf{C 4}$ & $\mathbf{C 5}$ \\
\hline$f_{1}$ & 0.326 & 1.000 & 1.000 & 0.000 & 0.000 \\
\hline$f_{2}$ & 0.674 & 0.000 & 0.000 & 0.150 & 0.866 \\
\hline$f_{3}$ & 0.000 & 0.000 & 0.000 & 0.850 & 0.134 \\
\hline
\end{tabular}




\begin{tabular}{|c|c|c|c|c|c|}
\hline$f_{4}$ & 0.000 & 0.000 & 0.000 & 0.000 & 0.000 \\
\hline$f_{5}$ & 0.000 & 0.000 & 0.000 & 0.000 & 0.000 \\
\hline AS-Qcho-08 & $\mathbf{C 1}$ & $\mathbf{C 2}$ & $\mathbf{C 3}$ & $\mathbf{C 4}$ & $\mathbf{C 5}$ \\
\hline$f_{1}$ & 0.888 & 1.000 & 1.000 & 0.000 & 0.000 \\
\hline$f_{2}$ & 0.112 & 0.000 & 0.000 & 0.898 & 0.962 \\
\hline$f_{3}$ & 0.000 & 0.000 & 0.000 & 0.102 & 0.038 \\
\hline$f_{4}$ & 0.000 & 0.000 & 0.000 & 0.000 & 0.000 \\
\hline$f_{5}$ & 0.000 & 0.000 & 0.000 & 0.000 & 0.000 \\
\hline $\mathbf{A S - Q \mathbf { c h o - 1 0 }}$ & $\mathbf{C 1}$ & $\mathbf{C 2}$ & $\mathbf{C 3}$ & $\mathbf{C 4}$ & $\mathbf{C 5}$ \\
\hline$f_{1}$ & 0.579 & 1.000 & 1.000 & 0.000 & 0.000 \\
\hline$f_{2}$ & 0.421 & 0.000 & 0.000 & 0.771 & 0.854 \\
\hline$f_{3}$ & 0.000 & 0.000 & 0.000 & 0.229 & 0.146 \\
\hline$f_{4}$ & 0.000 & 0.000 & 0.000 & 0.000 & 0.000 \\
\hline$f_{5}$ & 0.000 & 0.000 & 0.000 & 0.000 & 0.000 \\
\hline $\mathbf{A S - M i l - 0 2}$ & $\mathbf{C 1}$ & $\mathbf{C 2}$ & $\mathbf{C 3}$ & $\mathbf{C 4}$ & $\mathbf{C 5}$ \\
\hline$f_{1}$ & 0.492 & 1.000 & 1.000 & 0.113 & 0.028 \\
\hline$f_{2}$ & 0.508 & 0.000 & 0.000 & 0.887 & 0.972 \\
\hline$f_{3}$ & 0.000 & 0.000 & 0.000 & 0.000 & 0.000 \\
\hline$f_{4}$ & 0.000 & 0.000 & 0.000 & 0.000 & 0.000 \\
\hline$f_{5}$ & 0.000 & 0.000 & 0.000 & 0.000 & 0.000 \\
\hline
\end{tabular}

\section{d) Grey Class}

Finally, the maximum value of each point sampled (highlighted in yellow for a better appreciation in Table XVII) will be the grey class, which indicates the quality of the water.

TABLE XVII

RESULTS IN EACH POINT

\begin{tabular}{|c|c|c|c|c|c|c|c|}
\hline & \multicolumn{7}{|c|}{ SULTS IN EACH POIN } \\
\hline & $\begin{array}{l}\text { Standard data } \\
\text { nomenclature }\end{array}$ & $\lambda^{1}$ & $\lambda^{2}$ & $\lambda^{3}$ & $\lambda^{4}$ & $\lambda^{5}$ & Results \\
\hline $\begin{array}{l}\mathbf{P} \\
1\end{array}$ & AS-Qcho-04 & $\begin{array}{c}0.24 \\
3\end{array}$ & $\begin{array}{c}0.00 \\
0\end{array}$ & $\begin{array}{c}0.26 \\
3\end{array}$ & $\begin{array}{c}0.28 \\
0\end{array}$ & $\begin{array}{c}0.07 \\
0\end{array}$ & $\begin{array}{c}\text { Contamina } \\
\text { ted }\end{array}$ \\
\hline $\begin{array}{l}\mathbf{P} \\
2\end{array}$ & AS-Qcho-06 & $\begin{array}{c}0.30 \\
4\end{array}$ & $\begin{array}{c}0.57 \\
5\end{array}$ & $\begin{array}{c}0.00 \\
5\end{array}$ & $\begin{array}{c}0.00 \\
0\end{array}$ & $\begin{array}{c}0.00 \\
0\end{array}$ & Acceptable \\
\hline $\begin{array}{l}\mathbf{P} \\
\mathbf{3}\end{array}$ & AS-Qcl & $\begin{array}{c}0.24 \\
7\end{array}$ & $\begin{array}{c}0.32 \\
0\end{array}$ & $\begin{array}{c}0.25 \\
4\end{array}$ & $\begin{array}{c}0.00 \\
0\end{array}$ & $\begin{array}{c}0.00 \\
0\end{array}$ & Acceptable \\
\hline $\begin{array}{l}\mathbf{P} \\
4\end{array}$ & AS-C & $\begin{array}{c}0.25 \\
5\end{array}$ & $\begin{array}{c}0.57 \\
9\end{array}$ & $\begin{array}{c}0.03 \\
5\end{array}$ & $\begin{array}{c}0.00 \\
0\end{array}$ & $\begin{array}{c}0.00 \\
0\end{array}$ & Acceptable \\
\hline $\begin{array}{l}\mathbf{P} \\
\mathbf{5}\end{array}$ & AS-Q & $\begin{array}{c}0.25 \\
1\end{array}$ & $\begin{array}{c}0.52 \\
2\end{array}$ & $\begin{array}{c}0.09 \\
0\end{array}$ & $\begin{array}{c}0.00 \\
0\end{array}$ & $\begin{array}{c}0.00 \\
0\end{array}$ & Acceptable \\
\hline $\begin{array}{l}P \\
6\end{array}$ & AS-Mil-02 & $\begin{array}{c}0.30 \\
5\end{array}$ & $\begin{array}{c}0.59 \\
9\end{array}$ & $\begin{array}{c}0.00 \\
0\end{array}$ & $\begin{array}{c}0.00 \\
0\end{array}$ & $\begin{array}{c}0.00 \\
0\end{array}$ & Acceptable \\
\hline
\end{tabular}

\section{RESULTS AND DISCUSSION}

It has been possible to obtain that, through national regulations, the water samples in points $\mathrm{P} 2, \mathrm{P} 3, \mathrm{P} 4$ and $\mathrm{P} 5$ shown in Table XI are in the category of water that needs to be purified with disinfection. Whereas, point P1, shown in Table $\mathrm{XI}$, is found in the category of waters that need to be purified with advanced treatment. Thus, it turns out to be the one with the worst water quality even though in the report it is indicated as treated industrial water. Therefore, according to the results of the grouping coefficient, we can ensure that its water treatment is not adequate.

Likewise, the sample point of the Milo basin (P6 in Table $\mathrm{XI})$, is the one with the best water quality corroborating the OEFA report [3], which indicates that it complies with ECA water [7].

The order from highest contamination to lowest contamination according to the results of the grouping coefficients shown in Table XI is as follows:

\section{AS-QCho-04 > AS-QCho-07 > AS-QCho-10 > AS-QCho- $06>$ AS-Mil-02 >AS-QCho-08}

On the other hand, the water samples obtained by the Prati index at points $\mathrm{P} 2, \mathrm{P} 3, \mathrm{P} 4, \mathrm{P} 5$ and $\mathrm{P} 6$ (Table XVIII) correspond to the acceptable category, this result is taking into consideration the grouping coefficient [14]. Whereas, point P1 (Table XVIII) is the one with the highest contamination according to the category of Prati [6] since it has the highest value in its clustering coefficient [14].

The order from highest to lowest pollution according to the above-mentioned coefficient is as follows:

\section{AS-QCho-04 > AS-QCho-07 > AS-QCho-10 > AS-QCho- $06>$ AS-QCho-08 > AS-Mil-02}

In addition, considering a study conducted on the Rímac River [5], which mentions that anthropogenic activities cause pollution from its effluents, the case of our mining study is the anthropogenic activity that is emitting effluents and is likely to be the cause of pollution in our study area.

Finally, this method (Grey Clustering) was used for the evaluation of water quality because it takes into account the uncertainty in the analysis of the data [15], since multi-criteria methods known as MAUT and AHP do not consider uncertainty in their analysis [16]. Likewise, the results obtained are similar in both categories of analysis (ECA water and Prati) so it can be said that the results are more reliable [17].

By using the methodology with the Prati index, a greater variation of results was found, which is good because it allows us to determine the scale of contamination of the sampled points. On the other hand, when using the values according to the Water Quality Standards, only one point was found with greater contamination and with the other 4 it is not possible to determine which is the greatest contamination since the values obtained are the same.

\section{CONCLUSIONS}

The grey clustering method was directly applicable to the present case study. The results obtained indicate that point P1 (AS-Qcho-04) is contaminated even though it is a discharge of treated industrial water from the cyanide destruction plant, so it would be recommended to improve the effluent $\mathrm{D}$ treatment process. 
The grey clustering method has many advantages. It allows us to evaluate water quality when there is scarce data. It is of rapid application that indicates us the state of quality of the sampled point; reason why if a contaminated point is found it is possible to act quickly to remedy the contamination. In addition to being a reliable method because it incorporates uncertainty in the analysis.

In future studies, the Grey Clustering method could be applied to other types of environmental problems, water resource management, air quality. Given the advantages described above, more studies will give a better overview of the environmental situation in our country.

\section{REFERENCES}

[1] S. Vera, "Evaluación de los factores ambientales del plan de cierre de mina en la unidad minera aurifera Anabi," Universidad Nacional de Trujillo, 2014.

[2] RPP Noticias, "Pobladores queman campamento minero en distrito de Quiñota," 12-Nov-2016.

[3] OEFA, "INFORME N086-2017-OEFA/DE-SDLB-CEAME," 2017.

[4] I. Mohamed, F. Othman, A. I. N. Ibrahim, M. E. Alaa-Eldin, and R. M. Yunus, "Assessment of water quality parameters using multivariate analysis for Klang River basin, Malaysia," Environ. Monit. Assess., vol. 187, no. 1, pp. 1-12, Nov. 2015, doi: 10.1007/s10661-014-4182-y.

[5] A. Delgado, A. Aguirre, E. Palomino, and G. Salazar, "Applying triangular whitenization weight functions to assess water quality of main affluents of Rimac river," in Proceedings of the 2017 Electronic Congress, E-CON UNI 2017, 2017, vol. 2018-January, pp. 1-4, doi: 10.1109/ECON.2017.8247308.

[6] L. Prati, R. Pavanello, and F. Pesarin, "Assessment of surface water quality by a single index of pollution," Water Res., vol. 5, no. 9, pp. 741-751, 1971, doi: 10.1016/0043-1354(71)90097-2.

[7] MINAM, "Estándares de Calidad Ambiental (ECA) para Aire y establecen Disposiciones Complementarias," El Peru., pp. 6-9, 2017.

[8] D. Julong, "Grey system (society · economy)," Defense Industry Press, Peking, pp. 1-10, 1985.

[9] A. Delgado, D. Vriclizar, and E. Medina, "Artificial intelligence model based on grey systems to assess water quality from Santa river watershed," in Proceedings of the 2017 Electronic Congress, E-CON UNI 2017, 2017, vol. 2018-January, pp. 1-4, doi: 10.1109/ECON.2017.8247310.

[10]K. Liu, S. Xiaoliub, T. Zhongfu, and G. Wenyan, "Grey Clustering Analysis Method for Overseas Energy Project Investment Risk Decision," Syst. Eng. Procedia, vol. 3, pp. 55-62, 2012, doi: 10.1016/j.sepro.2011.11.008.

[11]A. Delgado and I. Romero, "Applying the Grey Systems Theory to Assess Social Impact from an Energy Project," in 2018 IEEE XXV International Conference on Electronics, Electrical Engineering and Computing (INTERCON), 2018, pp. 1-4, doi: 10.1109/INTERCON.2018.8526372.

[12]Q. Guo and Y. Li, "The application of the unascertained measure model in water environment evaluation of lakes," Environmetal Prot., vol. 4, pp. 2728, 2001

[13]M. Bao-hui, L. Chuang, F. Qiang, and L. Qinghua, "Attribute Recognition Model to Evaluate on Lake (Reservoir) Eutrophication," J. Sichuang Univ. (Engineering Sci. Edtion), vol. 34, no. 6, pp. 109-111, 2002.

[14]L. Zhou and S. Xu, "Zhou and Xu, Application of Grey Clustering Method," 2006.

[15]S. Liu and Y. Lin, Grey Systems: Theory and Applications. Berlín: Springer, 2010.

[16]B. Muñoz and M. Romana, "Aplicación de métodos de decisión multicriterio discretos al análisis de alternativas en estudios informativos de infraestructuras de transporte," Rev. "Pensamiento Matemático," vol. 6, no. 2, pp. 27-46, 2016.

[17]A. Delgado and H. Flor, "Selection of the best air purifier system to urban houses using AHP," in 2017 CHILEAN Conference on Electrical, Electronics Engineering, Information and Communication Technologies, CHILECON 2017 - Proceedings, 2017, vol. 2017-January, pp. 1-4.

$18^{\text {th }}$ LACCEI International Multi-Conference for Engineering, Education, and Technology: "Engineering, Integration, and Alliances for a Sustainable Development" "Hemispheric Cooperation for Competitiveness and Prosperity on a Knowledge-Based Economy", 29-31 July 2020, Buenos Aires, Argentina. 